\title{
Strip Dosage Form
}

National Cancer Institute

\section{Source}

National Cancer Institute. Strip Dosage Form. NCI Thesaurus. Code C47914.

A solid composed of active and/or inert ing redient(s) in a long narrow piece of material. 